Available online at: http:// http://tsdr.psdku.unpad.ac.id

Tourism and Sustainable Development Review-Journal (TSDR)

ISSN 2722-2152 (online)

Volume 1 Number 2 (Year): 94-102

\title{
SWOT Analysis As An Instrument For Strategic Planning Of Batik Kayu Craft Small Medium-Sized Enterprises (SMEs) In Krebet Bantul Yogyakarta
}

\author{
Yenni Sri Utami, Oliver Samuel Simanjuntak, Vynska Amalia Permadi, Agus Sasmita \\ Universitas Pembangunan Nasional Veteran Yogyakarta, Indonesia
}

\begin{abstract}
Krebs Tourism Village is a tourism destination that specifically produces the creative industries of Batik Kayu crafts. Small Micro Medium-Sized Enterprises of Batik Kayu craft in Krebet have developed rapidly and become a specific icon of Krebet Tourism Village. The unique styles of Batik upon wooden media have attracted both domestic and international customers. This research purpose to formulate the efficient strategies that can be applied to extend the growth of Batik Kayu craft in Krebs. This paper adopts the method of SWOT analysis to obtain a comprehensive evaluation of this SME Industries. Field observations and direct interviews have carried out with numerous Batik Kayu industrialists. This research only addresses the process of new Batik Kayu product variations development, information, and communication technology-based marketing network utilization, as well as the shortened supply processes from producers to consumers. The proposed strategies are new strategies that have never been implemented before in our partner region. Our contributions were acknowledged to increase sales capacity, extend the markets, and diminish the distribution layers to increase profits.
\end{abstract}

Keywords: SWOT Analysis, Batik Kayu craft, Small Medium-Sized Enterprises (SMEs), CommunityBased Tourism (CBT)

This is an open access article under the CC-BY-NC license.

\section{INTRODUCTION}

One of the regions in DIY that should be used as a pilot in alleviating poverty is the Krebet Tourism Village. Krebet Tourism Village is a tourism village that has succeeded in empowering people to focus and be consistent in the creative industry of wood batik and its products are well known abroad. Krebet Tourism Village is located in Sendangsari Village, Pajangan Subdistrict, Bantul Regency, and is a tourist village that has superior tourism icons for wooden batik crafts.

The skills of the Krebet Village community in innovating and producing batik works with wood media make this village the center of wooden batik crafts that are the hallmark of the village. The distinctive characteristics of batik with wood media attract the interest of both domestic and international buyers. The tourists are interested in visiting the Krebet Tourism Hamlet not just to buy various types of wooden batik, even to find out how the manufacturing process, community traditions, and enjoy the village atmosphere in a few days. This tourism village has considerable tourism potential that includes natural attractions, cultural tourism, education tourism (education), and culinary tourism. 
Krebet Tourism Village is a wooden batik craft center supported by the potential of natural and cultural tourism. The Krebet Tourism Village has also become a center for wooden batik crafts that have penetrated national and international markets. The vision of the Krebet Tourism Village is "Making the Krebet Tourism Village as a natural tourism and educational tourism area that is advanced and community-based" As a Krebet Tourism Village based on community-based tourism to be sustainable, marketing communication strategies are needed.
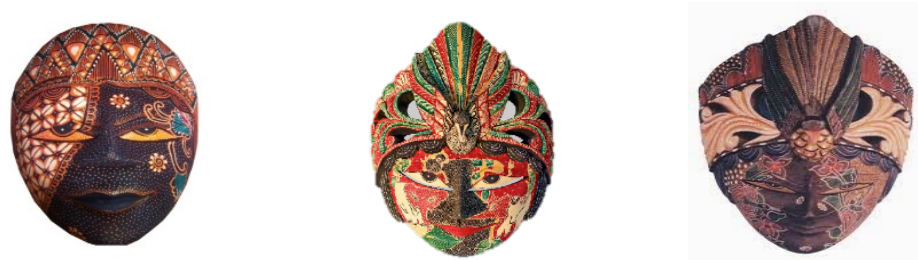

Figure 1. Wooden Batik Handicraft in Krebet Village

Each studio has specifications in its wooden batik products. Such as making wooden batik with the shape of a glass frame, tissue holder, key chain, puppet statue, accessories, and so on. In terms of promotion, each studio operates different marketing. The strategies used include electronic media, social networks, and some carry out promotions only through print media (newspapers and brochures) so that each studio produces a different income.

At present, the new Krebet Tourism Village has the status as a Tourism Attraction (DTW) of the Bantul Regency. To become a Tourist Destination, the Krebet Tourism Village still needs more development to qualify as a Tourist Destination, including the development of the area around the Krebet Tourism Village, as well as the provision of public facilities and tourism that have not yet been fulfilled. To reach the destination as a Tourist Destination, it requires a process and cooperation of various related parties to continuously increase the attractiveness of tourists to visit. Krebet Tourism Village also needs marketing activities to bring tourists. Marketing communication is an important aspect of the overall marketing mission to facilitate the delivery of meaning disseminated to customers, in this case, tourists.

Wooden batik studios generally can produce wooden batik in large enough volumes. Marketing focuses on manual methods through showrooms in the center of Krebet Village, through cooperatives and also through exhibitions held by the government. Further marketing, for example, exports to other countries, has been done but only incidental and more often through the services of third parties (intermediaries). Marketing using social media is still limited. The same thing happened with other UKMs in Krebet Village. Efforts to develop the Batik Kayu SME business in Krebet also encountered various obstacles. Especially since the CAFTA (China Asean Free Trade Agreement) era in 2010, Chinese products have flooded the Indonesian market. Currently, the challenge and opportunity for Batik Kayu SMEs are to face the Asean Economic Community in 2015 in marketing their products in the ASEAN market. The question in this research is how Batik Kayu SMEs in Bantul Regency can improve product marketing and provide quality sales services globally. 


\section{LITERATURE REVIEW}

Prior Research

Researches on the use of information technology for literacy and marketing of batik businesses have been carried out, among others, the making of E-Commerce for Omah Batik Semarangan online which has effectively increased the marketing of Omar batik Semarangan(Fatkhul Amin et al., 2012). The next research is the improvement of Batik Gumelem's image through a website-based information system(Retno Supriyanti et al., 2017) and continued with research on the design of a web-based Batik Sopiyan Hadi E-Commerce system which results in a web application for online batik ordering transactions (Dedi et al., 2017). Then there is similar research on the development of e-commerce information technology for Batik Bakaran to build a global market based on the resource-based view (RBV). The results of this study are e-commerce information technology as the spearhead of marketing with a resource-based view (RBV) approach to help improve the competitiveness of SMEs, especially for the burnt batik cluster Juwana-Pati (Mukhamad Nurkamid et al., 2017). The next research is about developing a web-based Batik Basurek sales information system at Bengkulu Basurek Collection. The conclusion of the research is business development by building an online website that analyzes sales can make it easier for customers to get information easily (Muhamad Muslihudin, 2013). The next research is the development of the Kampung Batik Jets website with the Rational Unified Process Method. The result is that black box testing using the use case testing technique shows that 18 of the features tested were all valid. While testing with the white box testing method with the base path testing technique produces three valid test results. Expected results with the existence of the website profile, residents especially batik Jetis Kampung craftsmen can promote the tourist village to the maximum (Rizal Joko Hidayatullah et al., 2018).

\section{Theoretical basis}

Context Input Process Product (CIPP) Evaluation Model. Evaluation of the Context Input Process Product (CIPP) model program considers all four aspects to be the process of an activity program. The CIPP model not only evaluates the results (outcomes) of a program, but also the environment, objectives, planning, and implementation of a program. Researchers use this method because the CIPP evaluation intends to compare the performance of various aspects of the program to finally arrive at an evaluation review regarding the strengths and weaknesses of the Krebet Tourism Village marketing communication strategy.

The CIPP evaluation model is an evaluation model that views a program that is evaluated as a unified activity that is composed of various components and is implemented. Stufflebeam (Daniel L. Stufflebeam \& Guili Zhang, 2017) explains the four aspects of evaluation are used to answer four basic questions in program evaluation. Among them, what are the goals or needs to be achieved? (what needs to be done?), how do you realize your goals or needs? (how should it be done?), how is the implementation? (is it being done?), and whether the results are by the objectives set? (did it succeed) The description of the evaluation components of the CIPP model is as follows.

First, the context aspect aims to see the relevance of the program to the background of the program. Evaluate the context by determining the needs, problems, assets, and opportunities and 
environmental conditions that are used to define program goals and priorities, and make the target objectives according to the estimated needs.

Second, evaluation of inputs by determining program strategies, activity plans, and management of human resources, provision of facilities, funding to meet the needs, and achievement of objectives. Sudjana (Sudjana, 2008) revealed that the evaluation of inputs included identification and evaluation activities in the form of the ability of the system used in the program, strategies to achieve program objectives and the design of the implementation of the specified strategies.

Third, evaluate the process by monitoring the implementation of the planned plans. Arikunto (Arikunto, 2005) revealed that the evaluation of the CIPP model process refers to the "what" activities carried out in the program, "who" (who) is shown to be responsible for the program, and "when" the activities will be completed. Furthermore, Arikunto said that in the CIPP model, the process evaluation was directed at the extent to which the activities carried out in the program were by the plan.

Fourth, product evaluation identifies and assesses the expenditure of costs and effects (outcomes) to measure the success rate of targets or goals that have been set. Also, the purpose of product evaluation is to assist program leaders and stakeholders by providing data that is used to assess program achievements, benefits, and costs (worth and cost) significantly.

The results of the evaluation of marketing communication programs, then to improve so that new programs can increase productivity, SWOT analysis is needed. The results of the SWOT analysis are in the form of 4 (four) strategic groups, namely:

a. Strategy to use the power to take advantage of opportunities (S-O strategy)

b. Strategy to eliminate weaknesses to take advantage of opportunities (W-O Strategy)

c. Strategy to use power to overcome threats (S-T strategy)

d. Strategy to reduce weaknesses to overcome threats (W-T Strategy).

The results of this SWOT analysis will then be input in determining the information needs needed to support the implementation of the strategy.

\section{RESEARCH METHOD}

This research is a type of mixed-method research that is a merger of quantitative and qualitative research methods (Prof. Dr. Sugiyono, 2007). The subject of this research is the manager of the Krebet Tourism Village with the object of research being the focus of this research is the marketing communication strategy of the Krebet Tourism Village in developing wooden batik SMEs. The quantitative research was carried out through surveys and applied technical and nontechnical approach. The technical approach includes laboratories and fields closely related to web development and android applications using the waterfall approach method. While non-technical using PAR (Participatory Action research) method with qualitative background from the quantitative approach. Subjects as well as key respondents namely; some Batik Krebet craftsmen, Bantul Regency. Data collection techniques: observation, participatory action review, FGD, interview, and questionnaire. Android and web system analysis techniques: Analysis of a structured system using the Waterfall method. 


\section{FINDINGS AND DISCUSSION}

Preliminary surveys and observations have been carried out to see the strengths and weaknesses in the Krebet Village, especially in the Punokawan Studio. Interviews have been conducted with several wood batik entrepreneurs and some wood batik artisans. The problem that has been discovered is the problem of product marketing communication to the outside world. The reason is due to the limitations of human resources, technology, knowledge, and expertise in the promotion and communication of its products throughout the world. The results of these initial observations have been analyzed using SWOT analysis (strength, weakness, opportunity, threat). The results of the SWOT analysis are in Table 1 below.

Table 1. Results of the SWOT Analysis

\begin{tabular}{|c|c|}
\hline STRENGTH & WEAKNESS \\
\hline $\begin{array}{l}\text { 1. Wood batik raw materials are available } \\
\text { and sufficient. } \\
\text { 2. Wood batik artisans are available and } \\
\text { sufficient. } \\
\text { 3. The ability to make batik skills is very good } \\
\text { and gives unique results. } \\
\text { 4. Can produce orders in large quantities }\end{array}$ & $\begin{array}{l}\text { 1. The majority of marketing of wooden } \\
\text { batik studios are still manually } \\
\text { 2. The range of marketing is not broad, } \\
\text { especially in small-scale studios } \\
\text { 3. Marketing depends on third parties. } \\
\text { 4. Most do not yet understand technology } \\
4.0\end{array}$ \\
\hline OPPORTUNITY & THREAT \\
\hline $\begin{array}{l}\text { 1. Demand for wood batik is increasing } \\
\text { 2. Opportunities to sell products abroad are } \\
\text { very open } \\
\text { 3. Government support and large } \\
\text { universities } \\
\text { 4. The number of competitors outside the } \\
\text { Krebet Village is still small }\end{array}$ & $\begin{array}{l}\text { 1. Many domestic and foreign consumers } \\
\text { want online transactions } \\
\text { 2. Market directly / independently to } \\
\text { consumers without 3rd party } \\
\text { intermediaries }\end{array}$ \\
\hline
\end{tabular}

Based on the mapping of strengths, weaknesses, opportunities, and threats above, an analysis is carried out to look for strategies using existing strengths to take advantage of available opportunities (S-O Strategies) and use their strengths to overcome existing threats (S-T strategies). It also analyzed strategies to reduce the weaknesses they have in seizing opportunities that exist (W-O strategy) and overcoming existing threats (W-T strategy). The mapping of S-O, W-O, S-T, and $\mathrm{W}$-T strategies can be seen in Table 2 to Table 5 .

Table 2. Strength - Threat Strategy

\begin{tabular}{|c|c|c|}
\hline & & $\begin{array}{l}\text { THREAT } \\
\text { T1. Many domestic and foreign consumers } \\
\text { want online transactions } \\
\text { T2. Market directly / independently to } \\
\text { consumers without 3rd party } \\
\text { intermediaries }\end{array}$ \\
\hline
\end{tabular}


Tourism and Sustainable Development Review-Journal (TSDR), Vol. 1 (2), 94-105

SWOT Analysis As An Instrument For Strategic Planning Of Batik Kayu Craft Small Medium-Sized

Enterprises (SMEs) In Krebet Bantul Yogyakarta

Yenni Sri Utami, Oliver Samuel Simanjuntak, Vynska Amalia Permadi, Agus Sasmita

\section{STRENGTH}

S1. Wood batik raw materials are available and sufficient.

S2. Wood batik artisans are available and sufficient.

S3 The ability to make batik is very good and gives unique results.

S4 Can produce orders in large quantities.

\section{STRATEGY S-T}

T1 - S1 :

Develop online marketing facilities for galleries and wooden batik promotions in a wide variety of materials at home and abroad.

$\mathrm{T} 1$ - S2 + S3 :

Develop gallery facilities for the

$\mathrm{T} 1$ - S2 + S3 :

Promotion of superior products of the unique results of each crafter at home and abroad.

T2 - S4 :

These marketing facilities are managed by themselves without involving third parties (intermediaries).

Table 3. Strength - Opportunity Strategy

\begin{tabular}{|c|c|}
\hline & $\begin{array}{l}\text { OPPORTUNITY } \\
\text { 01. The demand for wood batik is increasing } \\
\text { O2. Opportunities to sell products abroad are } \\
\text { very open } \\
\text { O3. Large government and university } \\
\text { support } \\
\text { 04. The number of competitors outside the } \\
\text { Krebet Village is still small }\end{array}$ \\
\hline $\begin{array}{l}\text { STRENGTH } \\
\text { S1. Wood batik raw materials are available } \\
\text { and sufficient. } \\
\text { S2. Wood batik artisans are available and } \\
\text { sufficient. } \\
\text { S3. The ability to make batik is very good and } \\
\text { gives unique results. } \\
\text { S4. Can produce orders in large quantities }\end{array}$ & 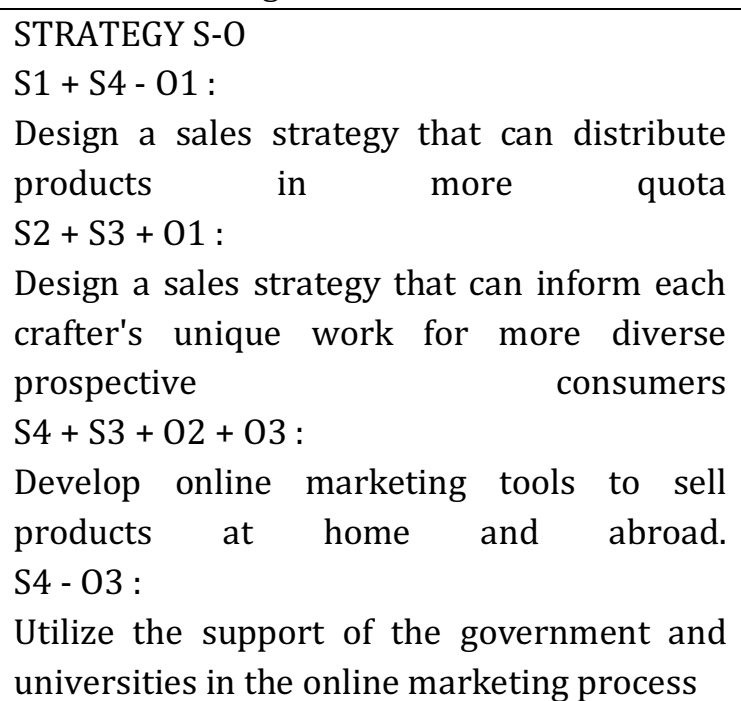 \\
\hline
\end{tabular}


Tourism and Sustainable Development Review-Journal (TSDR), Vol. 1 (2), 94-105

SWOT Analysis As An Instrument For Strategic Planning Of Batik Kayu Craft Small Medium-Sized

Enterprises (SMEs) In Krebet Bantul Yogyakarta

Yenni Sri Utami, Oliver Samuel Simanjuntak, Vynska Amalia Permadi, Agus Sasmita

Table 4. Weakness - Opportunity Strategy

\begin{tabular}{|c|c|}
\hline & $\begin{array}{l}\text { OPPORTUNITY } \\
\text { 01. The demand for wood batik is increasing } \\
\text { O2. Opportunities to sell products abroad are } \\
\text { very open } \\
\text { 03. Large government and university } \\
\text { support } \\
\text { 04. The number of competitors outside the } \\
\text { Krebet Village is still small }\end{array}$ \\
\hline $\begin{array}{l}\text { WEAKNESS } \\
\text { W1. The majority of the marketing of wooden } \\
\text { batik studios are still manually } \\
\text { W2. The range of marketing is not extensive, } \\
\text { especially in small-scale studios } \\
\text { W3. Marketing depends on third parties } \\
\text { W4. Most do not understand technology } 4.0\end{array}$ & $\begin{array}{l}\text { STRATEGY W-0 } \\
\text { W1 - } 01+02+04 \text { : } \\
\text { Develop better methods for marketing } \\
\text { mechanisms at home and abroad. } \\
\text { W3 - 03: } \\
\text { Utilizing the support of the government and } \\
\text { universities for independence in marketing } \\
\text { W4-03: } \\
\text { Focusing assistance from government and } \\
\text { universities for technology transfer } 4.0\end{array}$ \\
\hline
\end{tabular}

Table 5. Weakness - Threat Strategy

\begin{tabular}{|l|l|}
\hline & $\begin{array}{l}\text { THREAT } \\
\text { T1. Many domestic and foreign consumers } \\
\text { want online transactions } \\
\text { T2. Market directly / independently to } \\
\text { consumers without 3rd party } \\
\text { intermediaries }\end{array}$ \\
\hline $\begin{array}{l}\text { WEAKNESS } \\
\text { W1. The majority of the marketing of wooden } \\
\text { batik studios are still manually }\end{array}$ & $\begin{array}{l}\text { STRATEGY W-T } \\
\text { W1 + W2 - T1 : } \\
\text { Developing more efficient marketing tools to } \\
\text { especially in small-scale studios }\end{array}$ \\
$\begin{array}{l}\text { W3. Marketing depends on third parties } \\
\text { W4. Most do not understand technology 4.0 }\end{array}$ & $\begin{array}{l}\text { W3 - T2 : } \\
\text { Develop product marketing tools that can } \\
\text { inform products directly to consumers. } \\
\text { W4 - T1 :Providing knowledge about } \\
\text { technology 4.0 concerning online marketing }\end{array}$ \\
\hline
\end{tabular}

The results of the S-T, S-O, W-O, and W-T analyzes are summarized and summarized into real work programs that are ready to be implemented for empowering the marketing strategies of the batik wood crafters in Bantul Krebet Village. The process of summarizing is by re-registering all the S-T, $\mathrm{S}-\mathrm{O}, \mathrm{W}-\mathrm{O}$, and $\mathrm{W}-\mathrm{T}$ strategies in a table then sorted according to their level of importance. The results are as in Table 6. 
Tourism and Sustainable Development Review-Journal (TSDR), Vol. 1 (2), 94-105

SWOT Analysis As An Instrument For Strategic Planning Of Batik Kayu Craft Small Medium-Sized

Enterprises (SMEs) In Krebet Bantul Yogyakarta

Yenni Sri Utami, Oliver Samuel Simanjuntak, Vynska Amalia Permadi, Agus Sasmita

Table 6. Summarizing Results of All Strategies

\begin{tabular}{|c|c|c|c|}
\hline No & $\begin{array}{l}\text { Types of } \\
\text { Strategies }\end{array}$ & Forms of Work & Program Strategies \\
\hline 1 & $\begin{array}{l}\text { S-T, } \\
\text { W-O, } \\
\text { W-T, } \\
\text { S-O }\end{array}$ & $\begin{array}{l}\text { Develop online marketing tools for the } \\
\text { gallery and promotion of wooden batik in a } \\
\text { wide variety of materials at home and } \\
\text { abroad. }\end{array}$ & $\begin{array}{l}\text { Identify product advantages } \\
\text { based on the type of raw } \\
\text { material, then make a product } \\
\text { catalog that can be seen by } \\
\text { potential consumers online }\end{array}$ \\
\hline 2 & $\begin{array}{l}\text { S-T, } \\
\text { W-O, } \\
\text { W-T, } \\
\text { S-O }\end{array}$ & $\begin{array}{l}\text { Develop a gallery for the promotion of } \\
\text { superior products' unique results of each } \\
\text { crafter at home and abroad. }\end{array}$ & $\begin{array}{l}\text { Identify the uniqueness of the } \\
\text { product based on art workers } \\
\text { who have made it and then } \\
\text { create a product design } \\
\text { catalog that can be seen by } \\
\text { potential consumers online }\end{array}$ \\
\hline 3 & S-T & $\begin{array}{l}\text { These online marketing tools are managed } \\
\text { by themselves without involving third } \\
\text { parties (intermediaries). }\end{array}$ & $\begin{array}{l}\text { Introducing online marketing } \\
\text { concepts and practices for } \\
\text { creative craft entrepreneurs }\end{array}$ \\
\hline 4 & $\begin{array}{l}\text { S-O, } \\
\text { W-O, } \\
\text { W-T }\end{array}$ & $\begin{array}{l}\text { Design a sales strategy that can distribute } \\
\text { products in more quota } \\
\text { Utilize the support of government and } \\
\text { universities in the online marketing } \\
\text { process, independent, with a touch of } \\
\text { technology } 4.0\end{array}$ & $\begin{array}{l}\text { Develop online marketing } \\
\text { models with large-scale } \\
\text { product distribution to } \\
\text { several consumers at home / } \\
\text { abroad }\end{array}$ \\
\hline 5 & $\begin{array}{l}\text { S-O, } \\
W-0\end{array}$ & $\begin{array}{l}\text { Design a sales strategy that can distribute } \\
\text { products in more quota } \\
\text { Utilize the support of government and } \\
\text { universities in the online marketing } \\
\text { process, independent, with a touch of } \\
\text { technology } 4.0\end{array}$ & $\begin{array}{l}\text { Focusing government or } \\
\text { tertiary assistance programs } \\
\text { on online marketing } \\
\text { capabilities and } \\
\text { mastery } 4.0\end{array}$ \\
\hline
\end{tabular}

The five forms of strategy summarized in Table 4 will be continued in the form of concrete work programs. The real work program must first know its purpose, its targets, then the steps of implementing the work program and evaluating it periodically. Krebet Tourism Village does not use advertising media through television, radio, and print media. At the implementation stage of the marketing communication strategy of the Krebet Tourism Village, there were several programs implemented. First, the Krebet Tourism Village participated in programs from the Tourism Office such as actively participating in exhibitions at regional, national and international levels, travel dialogues, tabletop, and were involved in the Bantul Tourism Office's "Bantul Tourism" application content. The Krebet Tourism Village then has a production program for promotional tools such as making brochures, posters, managing websites, and social media. Other marketing communication strategy programs undertaken by the Krebet Tourism Village are organizing events such as "Merti Dusun", workshops and art shows. 
Tourism and Sustainable Development Review-Journal (TSDR), Vol. 1 (2), 94-105

SWOT Analysis As An Instrument For Strategic Planning Of Batik Kayu Craft Small Medium-Sized

Enterprises (SMEs) In Krebet Bantul Yogyakarta

Yenni Sri Utami, Oliver Samuel Simanjuntak, Vynska Amalia Permadi, Agus Sasmita

After the implementation phase is carried out, the manager of the Krebet Tourism Village conducts an evaluation every two months to review the visits of tourists in the Krebet Tourism Village. When viewed graphically there is not always an increase every year and there are fluctuations in the number of tourists visiting, in 2017 the Krebet Tourism Village has decreased visitors. However, with the change in the promotion strategy that has been reviewed, the number of tourists has increased. From the marketing communication strategy of the Krebet Tourism Village, the most effective program that can be said is the use of websites, recommendations or word of mouth, and sales promotion in the form of discounts to travel agents.

\section{CONCLUSION}

The main conclusion of the results of this study is that the Krebet Tourism Village needs facilities for product promotion, a gallery that can publish unique batik woodworks to prospective consumers both at home and abroad. These tools can be in the form of a marketplace to introduce studios, works and ultimately to support bookings and sales transactions. The facility should be managed independently so that it can provide optimal benefits. An interactive communication process with prospective tourists in the Krebet tourism village or you can add links directly to Krebet social media. The Krebet Tourism Village Marketing Communication Strategy program should be continued by correcting some deficiencies in the aspects that have been evaluated in this study.

\section{REFERENCES}

D. Sudjana. (2008). Evaluasi Program Pendidikan Luar Sekolah. Remaja Rosdkarya.

Daniel L. Stufflebeam, \& Guili Zhang. (2017). The CIPP Evaluation Model: How to Evaluate for Improvement and Accountability. Guilford Publications.

Dedi, Triono, \& Wahdah Muhajiroh. (2017). Perancangan Sistem E-Commerce Batik Sopiyan Hadi Berbasis Web. Jurnal Sisfotek Global, 7(1), 124-129.

Fatkhul Amin, R. Soelistijadi, \& Aji Priambodo. (2012). Aplikasi E-Commerce Sentra Batik di Kota Semarang Sebagai Salah Satu Upaya Media Promosi dan Transaksi Secara Online. Jurnal Teknologi Informasi DINAMIK, 17(1), 67-74.

Muhamad Muslihudin. (2013). Sistem Informasi Penjualan Batik Basurek Berbasis Web Pada Basurek Collection Bengkulu. Jurnal Technology Acceptance Model (TAM), 1(8), 59-62.

Mukhamad Nurkamid, Budi Gunawan, \& Sri Mulyani. (2017). Teknologi Informasi E-commerce Untuk Batik Bakaran Dalam Membangun Pasar Global Berbasis Resource Base View (RBV). Prosiding Seminar Nasional Teknologi Dan Informatika, 2(36), 255-263.

Prof. Dr. Sugiyono. (2007). Metode Penelitian Kuantitatif, Kualitatif, dan R\&D. Alfabeta.

Retno Supriyanti, Eko Murdyantoro, \& Priswanto. (2017). Peningkatan Citra Batik Gumelem Melalui Sistem Informasi Berbasis Website Dan Perbaikan Sarana Prasarana. Jurnal Telematika, 10(2), 136-150.

Rizal Joko Hidayatullah, Niken Hendrakusma Wardani, \& Aditya Rachmadi. (2018). Pengembangan Website Kampung Batik Jetis Dengan Metode Rational Unified Process. Jurnal Pengembangan Teknologi Informasi Dan Ilmu Komputer, 2(11), 4347-4356.

S. Arikunto. (2005). Dasar-Dasar Evaluasi Pendidikan. Bumi Aksara. 